\title{
Fraunhofer
}

\section{CURRENT STATUS OF CONCENTRATOR PHOTOVOLTAIC (CPV) TECHNOLOGY}
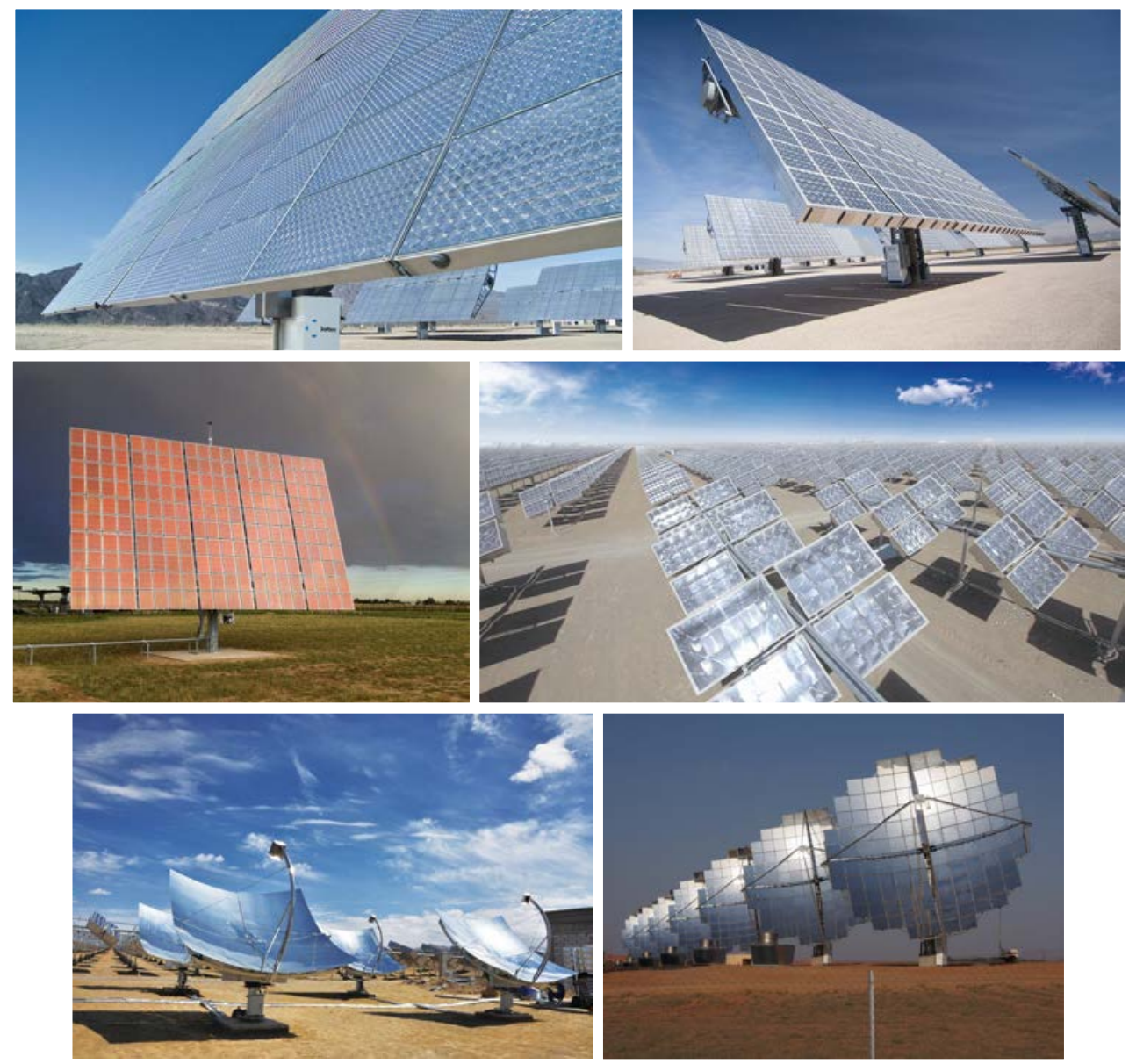


\section{NOTICE}

This report was prepared as an account of work sponsored by an agency of the United States government and by the Fraunhofer Institute of Solar Energy Systems ISE, Germany. Neither the United States government nor any agency thereof, nor the Fraunhofer ISE, nor any of their employees, makes any warranty, express or implied, or assumes any legal liability or responsibility for the accuracy, completeness, or usefulness of any information, apparatus, product, or process disclosed, or represents that its use would not infringe privately owned rights. Reference herein to any specific commercial product, process, or service by trade name, trademark, manufacturer, or otherwise does not necessarily constitute or imply its endorsement, recommendation, or favoring by the United States government or any agency thereof or the Fraunhofer ISE. The views and opinions of authors expressed herein do not necessarily state or reflect those of the United States government or any agency thereof or the Fraunhofer ISE.

This report is available at no cost from the Fraunhofer Institute for Solar Energy Systems ISE at www.ise.fraunhofer.de/en/renewable-energy-data and the National Renewable Energy Laboratory (NREL) at www.nrel.gov/publications.

Fraunhofer ISE and NREL print on paper that contains recycled content.

Available electronically at SciTech Connect http:/www.osti.gov/scitech

Available for a processing fee to U.S. Department of Energy and its contractors, in paper, from:

U.S. Department of Energy

Office of Scientific and Technical Information

P.O. Box 62

Oak Ridge, TN 37831-0062

phone: 865.576 .8401

fax: 865.576 .5728

email: reports@osti.gov

Available for sale to the public, in paper, from:

U.S. Department of Commerce

National Technical Information Service

5301 Shawnee Road

Alexandria, VA 22312

phone: 800.553 .6847 or 703.605 .6000

fax: 703.605 .6900

email: orders@ntis.gov

Fraunhofer ISE is a member of the Fraunhofer-Gesellschaft, Europe's largest application-oriented research organization.

NREL is a national laboratory of the U.S. Department of Energy, Office of Energy Efficiency and Renewable Energy, operated by the Alliance for Sustainable Energy, LLC. 


\section{CURRENT STATUS OF CONCENTRATOR PHOTOVOLTAIC (CPV) TECHNOLOGY}

Version 1.1, December 2015

Dr. Simon P. Philipps, Dr. Andreas W. Bett

Fraunhofer Institute for Solar Energy Systems ISE in Freiburg, Germany

Kelsey Horowitz, Dr. Sarah Kurtz

National Renewable Energy Laboratory NREL

in Golden, Colorado, USA 


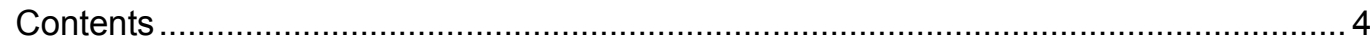

Key Facts …

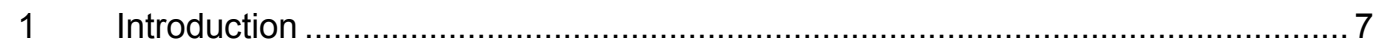

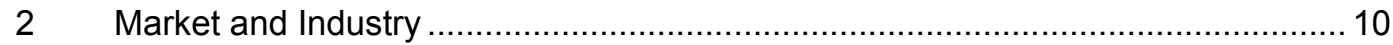

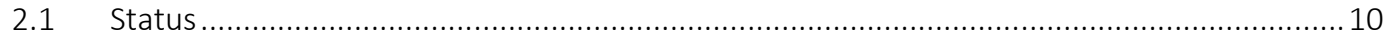

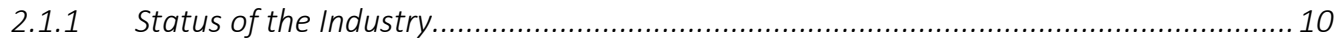

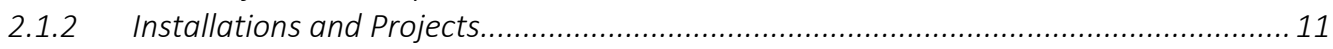

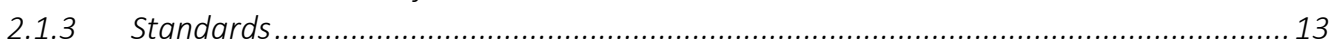

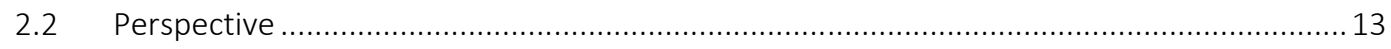

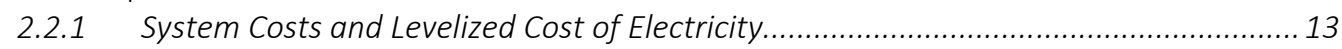

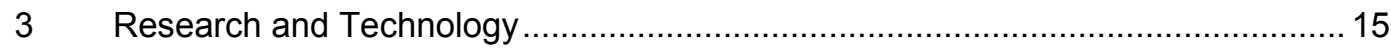

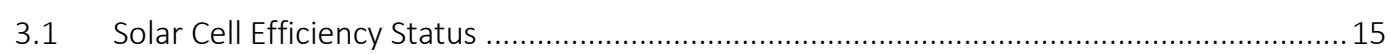

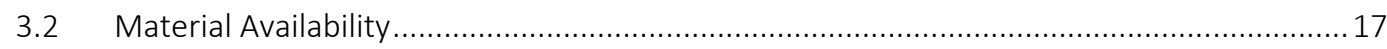

$4 \quad$ References

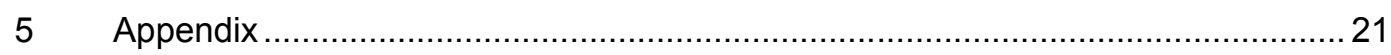

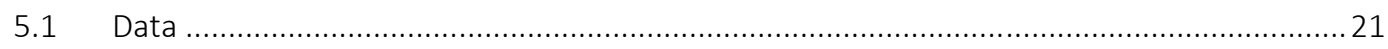

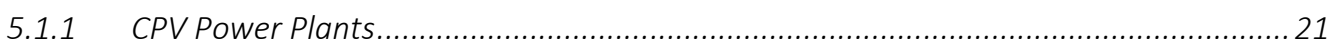

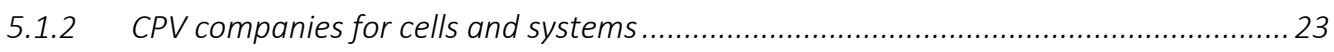

\section{Introductory Note}

This report summarizes the status of the concentrator photovoltaic (CPV) market and industry as well as current trends in research and technology. This report is intended to guide research agendas for Fraunhofer ISE, the National Renewable Energy Laboratory (NREL), and other R\&D organizations.

Version 1.1 of this report includes recent progress in CPV. The recent record module efficiency of $38.9 \%$ at Concentrator Standard Test Conditions (CSTC) is an impressive result, demonstrating the continuing opportunity for CPV technology to improve.

If you have suggestions about this report, additional or updated information, or would like to add your organization's information to our tables, please e-mail simon.philipps@ise.fraunhofer.de. It is our intention to update the report in a regular manner.

Cover Photos (top left to bottom right): (C) Soitec; (C) Arzon Solar, LLC; (C) Semprius; (C) Suncore;

(c) Suncore; (c) Solar Systems

\begin{tabular}{l}
\hline Fraunhofer ISE | NREL CPV Report 1.1 \\
Fraunhofer ISE is a member of the Fraunhofer-Gesellschaft, Europe's largest application-oriented research organization. \\
NREL is a national laboratory of the U.S. Department of Energy, Office of Energy Efficiency and Renewable Energy, operated by \\
the Alliance for Sustainable Energy, LLC.
\end{tabular}


Notable developments in the CPV market and industry in recent years include:

- Cumulative installations (already grid-connected): $340 \mathrm{MW}_{\mathrm{p}}$

- Several power plants with capacity $\geq 30 \mathrm{MW}_{\mathrm{p}}$ :

- Golmud, China, built by Suncore: 60 and $80 \mathrm{MW}_{\mathrm{p}}$

- Touwsrivier, South Africa, built by Soitec: $44 \mathrm{MW}_{\mathrm{p}}$

- Alamosa, Colorado, US, built by Amonix: $30 \mathrm{MW}_{\mathrm{p}}$ (see installation data base: http://cpvconsortium.org/projects)

- $\quad$ Proven reliability and field data for more than 6 years [1]

- Worldwide manufacturing capacities $700 \mathrm{MW}$ per year, but in the near future a reduction is expected

Various developments in CPV research and technology have been achieved as well, including:

- Certified record value for solar cell efficiency of $46.0 \%$ by Fraunhofer ISE, Soitec, CEA-LETI [2,3]

- Certified record value for module efficiency of $38.9 \%$ by Soitec [4]

- $\quad$ Averaged yearly field performance data for power plants with $>100 \mathrm{kWp}$ were reported with performance ratios of $74-80 \%$ achieved [1]

- Recent R\&D results can be found in the proceedings of the latest International CPV conference. The next CPV conference will take place in Freiburg, Germany and is planned for April $2016^{1}$.

\section{What's New?}

Version 1.1 of this report has been thoroughly revised compared to Version 1 from January 2015. The authors like to especially point the reader's attention to the following updates:

- $\quad$ New record of HCPV module efficiency of 38.9\% (former record 36.7\%).

- Installation data were updated to include the full year 2014.

- Company tables in the appendix were updated and now include links to the company websites.

- $\quad$ The company Soitec S.A. France, a major player in the CPV business, announced in a press release on January $19^{\text {th }}, 2015$ and April $20^{\text {th }}, 2015$ its intentions to refocus on its core business of electronics and to re-structure its solar business (i.e CPV business) $)^{2}$. In May $21^{\text {st }}, 2015$ another press release announced that another major player, Suncore, will be the new owner of the Soitec CPV assets ${ }^{3}$. In August $5^{\text {th }}$, 2015 Soitec announced that the closing of the deal will not occur ${ }^{4}$.

\footnotetext{
${ }^{1}$ http://scitation.aip.org/content/aip/proceeding/aipcp/1616; http://www.cpv-12.org

${ }^{2}$ http://www.soitec.com/en/news/press-releases/soitec-reports-q3-2014-2015-consolidated-sales-and-announcesstrategic-re-focus-on-its-core-electronics-business-1622/ and http://www.soitec.com/ en/news/ pressreleases/article-1696/

${ }^{3}$ http://www.soitec.com/en/investors/financial-press-releases/soitec-divests-its-solar-system-business-to-refocuson-its-core-semiconductor-activities-1722/

${ }^{4}$ http://www.soitec.com/en/news/press-releases/soitec-announces-the-end-of-negotiations-with-concensolarregarding-a-sale-of-solar-assets-and-continues-its-refocus-on-electronics-1772/
}

\begin{tabular}{llll|l}
\hline Fraunhofer ISE | NREL & CPV Report 1.1 & December 2015 & TP-5J00-65130
\end{tabular}


- $\quad$ Suncore, China is stopping their CPV production and is re-thinking their CPV Key Facts strategy. 
Concentrator Photovoltaic (CPV) technology has recently entered the market as a utilityscale option for the generation of solar electricity. This report explores the current status of the CPV market, industry, research, and technology. The CPV industry has struggled to compete with PV prices, with many companies exiting the market, leading to challenges in raising the capital required to scale. However, CPV modules continue to achieve efficiencies far beyond what is possible with traditional flat-plate technology and have room to push efficiencies even higher in the future, providing a potential pathway for significant reductions in systems costs.

The key principle of CPV is the use of cost-efficient concentrating optics that dramatically reduce the cell area, allowing for the use of more expensive, high-efficiency cells and potentially a levelized cost of electricity (LCOE) competitive with Concentrated Solar Power and standard flat-plate PV technology in certain sunny areas with high Direct Normal Irradiance (DNI) [5]. Figure 1 shows two exemplary concepts using Fresnel lenses and mirrors as concentrating optics.

CPV is of most interest for power generation in sun-rich regions with Direct Normal Irradiance (DNI) values of more than $2000 \mathrm{kWh} /\left(\mathrm{m}^{2} \mathrm{a}\right)$. The systems are differentiated according to the concentration factor of the technology configuration (see Table 1). More than $90 \%$ of the capacity publicly documented to be installed through end July 2015 is in the form of high concentration PV (HCPV) with two-axis tracking. Concentrating the sunlight by a factor of between $300 x$ to $1000 x$ onto a small cell area enables the use of highly efficient but comparatively expensive multi-junction solar cells based on III-V semiconductors (e.g. triplejunction solar cells made of GalnP/GalnAs/Ge). Low concentration designs - those with concentration ratios below $100 x$ - are also being deployed. These systems primarily use crystalline silicon (c-Si) solar cells and single-axis tracking, although dual axis tracking can also be used.
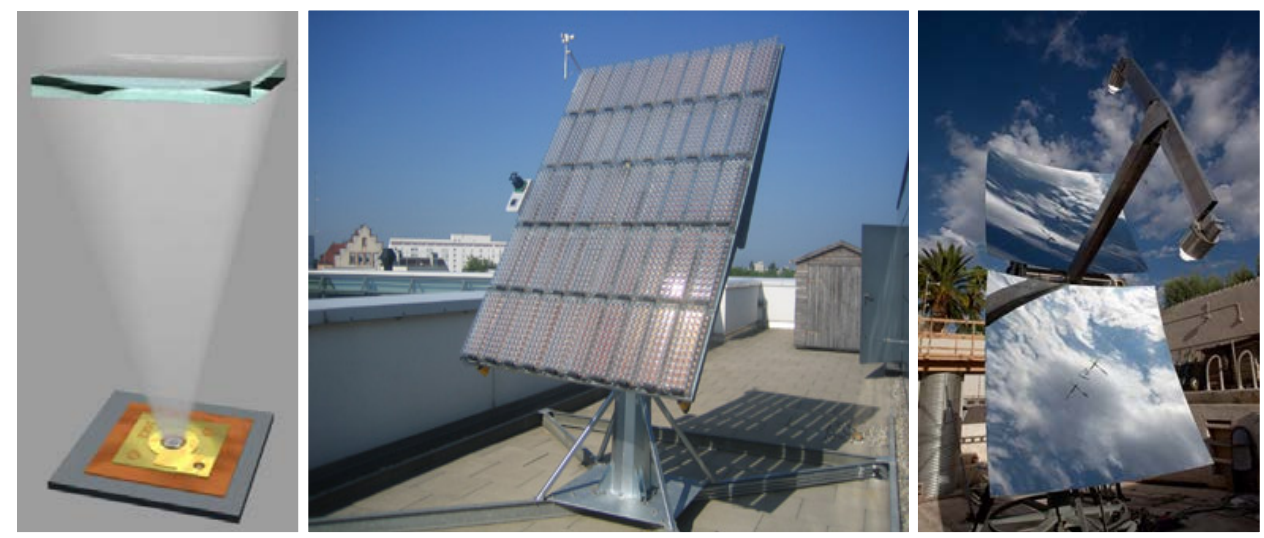

Figure 1: Left and middle: Example of a CPV system using Fresnel lenses to concentrate the sunlight: FLATCON $^{\circledR}$ concept originally developed at Fraunhofer ISE. Right: Example of a mirror-based system developed by the University of Arizona, USA [6].

A key reason for the increasing number of large-scale power plants using HCPV is the significant increase in the efficiency of individual modules, which also leads to a reduction of area-related system costs. Soitec recently demonstrated a CPV module efficiency of $38.9 \%$ at Concentrator Standard Test Conditions (CSTC) [4] and efficiencies of commercially available CPV modules exceed 30\%. In recent years, AC system efficiencies have also increased, reaching 25-29\% and companies predict further increases in efficiency for CPV systems to over $30 \%$ in the next couple of years driven largely by improvements in cell efficiency but

\begin{tabular}{llll}
\hline Fraunhofer ISE | NREL & CPV Report 1.1 & December 2015 & TP-5J00-65130
\end{tabular}


also in the optical efficiency $[7,8]$. In addition to these higher efficiencies, tracking allows CPV systems to produce a larger amount of energy throughout the day in sunny regions, notably during late part of the day when electricity demand peaks. At the same time and in contrast to CSP, the size of the installations can be scaled over a wide range, i.e from $\mathrm{kW}$ to multi$\mathrm{MW}$, and in this way adapted to the local demands. Some CPV systems also disturb a smaller land area, since the trackers, with relatively narrow pedestals, are not closely packed. This makes it possible to continue to use the land for agriculture. Finally, HCPV is advantageous in hot climates in particular, since the output of the solar cells used does not decline as severely at high temperatures as that of conventional c-Si solar modules.

\begin{tabular}{c|l|l|l}
\hline Class of CPV & \multicolumn{1}{|c|}{$\begin{array}{c}\text { Typical } \\
\text { concentration ratio }\end{array}$} & Tracking & Type of converter \\
\hline High Concentration PV (HCPV) & $300-1000$ & Two-axis & $\begin{array}{l}\text { III-V multi-junction } \\
\text { solar cells }\end{array}$ \\
\hline Low Concentration PV (LCPV) & $<100$ & $\begin{array}{l}\text { One or } \\
\text { two-axis }\end{array}$ & c-Si or other cells \\
\hline
\end{tabular}

Table 1: Description of CPV classes. $^{1}$

Industry interviews indicate that the total capital equipment (capex) requirement, while varying by design and manufacturing process, can be lower for CPV than for traditional flatplate technologies, including c-Si. Additionally, a bottom-up analysis from NREL based on a specific HCPV system with a Fresnel lens primary optic and refractive secondary lens estimates the total capex for cells and modules in this design (assuming a vertically integrated company) to be around $\$ 0.55 / \mathrm{Wp}(\mathrm{DC})$, with a much lower capex for variations on the design. Most HCPV companies have their optics and cells manufactured by a third party, in which case the capital equipment requirements for the HCPV company itself can be quite low.

Reports indicate that the installed system prices for CPV systems have declined significantly since the technology was introduced on the market [9]. In 2013, a Fraunhofer ISE report found that installed CPV power plant prices for $10 \mathrm{MW}$ projects were between $€ 1400 / \mathrm{kW}$ and $€ 2200 / \mathrm{kW}$ [5]. The wide range of prices results from the different technological concepts as well as the nascent and regionally variable markets. LCOEs based on these systems prices calculated by Fraunhofer ISE [5] range from $€ 0.10 / \mathrm{kWh}$ to $€ 0.15 / \mathrm{kWh}$ for a location with a DNI of $2000 \mathrm{kWh} /\left(\mathrm{m}^{2} \mathrm{a}\right)$ and $€ 0.08 / \mathrm{kWh}$ to $€ 0.12 / \mathrm{kWh}$ for $2500 \mathrm{kWh} /\left(\mathrm{m}^{2} \mathrm{a}\right)$. These numbers provide a basis for comparison of current CPV projects with the analyzed values for utility-scale PV and concentrating solar power (CSP) power plants, as will be discussed in more detail in section 2.2.1. Table 2 summarizes the strengths and weaknesses of CPV.

Although research on cells, modules, and systems for CPV has been ongoing for decades, CPV only entered the market in the mid-2000s. While it has seen strong market growth in recent years, it is still a young and - compared to conventional flat-plate PV - small player in the market for solar electricity generation. This implies a lack of reliable data for market, prices, and status of industry. The aim of this report is to help fill this information void by summarizing and providing reliable data on CPV. The first part of the report focuses on market and industry aspects, which might benefit investors, policy-makers, industry members, researchers who wish to place their research in a larger context, and the general public. The second part deals with research and technology and should primarily be a reference for stakeholders in the CPV industry and research.

${ }^{1}$ Systems with concentration factors between 100 and 300 are not included since their current configurations are not cost-competitive on LCOE-level to other CPV approaches.

\begin{tabular}{llll}
\hline Fraunhofer ISE | NREL & CPV Report 1.1 & December 2015 & TP-5J00-65130
\end{tabular}




\begin{tabular}{|c|c|}
\hline CPV Strengths & CPV Weaknesses \\
\hline $\begin{array}{l}\text { High efficiencies for direct-normal } \\
\text { irradiance }\end{array}$ & $\begin{array}{c}\text { HCPV cannot utilize diffuse radiation } \\
\text { LCPV can only utilize a fraction of diffuse } \\
\text { radiation }\end{array}$ \\
\hline Low temperature coefficients & $\begin{array}{l}\text { Tracking with sufficient accuracy and } \\
\text { reliability is required }\end{array}$ \\
\hline $\begin{array}{l}\text { No cooling water required for passively } \\
\text { cooled systems (as is required for CSP) }\end{array}$ & $\begin{array}{l}\text { May require frequent cleaning to mitigate } \\
\text { soiling losses, depending on the site }\end{array}$ \\
\hline $\begin{array}{l}\text { Additional use of waste heat possible for } \\
\text { systems with active cooling possible (e.g. } \\
\text { large mirror systems) }\end{array}$ & $\begin{array}{l}\text { Limited market - can only be used in } \\
\text { regions with high DNI, cannot be easily } \\
\text { installed on rooftops }\end{array}$ \\
\hline Modular - kW to GW scale & $\begin{array}{l}\text { Strong cost decrease of competing } \\
\text { technologies for electricity production }\end{array}$ \\
\hline $\begin{array}{l}\text { Increased and stable energy production } \\
\text { throughout the day due to tracking }\end{array}$ & $\begin{array}{l}\text { Bankability and perception issues due to } \\
\text { shorter track record compared to PV }\end{array}$ \\
\hline Very low energy payback time & $\begin{array}{l}\text { New generation technologies, without a } \\
\text { history of production (thus increased risk) }\end{array}$ \\
\hline $\begin{array}{l}\text { Potential double use of land, e.g. for } \\
\text { agriculture. Low environmental impact }\end{array}$ & Additional optical losses \\
\hline $\begin{array}{l}\text { Opportunities for cost-effective local } \\
\text { manufacturing of certain steps }\end{array}$ & Lack of technology standardization \\
\hline $\begin{array}{l}\text { Less sensitive to variations in } \\
\text { semiconductor prices }\end{array}$ & \\
\hline $\begin{array}{l}\text { Greater potential for efficiency increase in } \\
\text { the future compared to single-junction flat } \\
\text { plate systems could lead to greater } \\
\text { improvements in land area use, system, } \\
\text { BOS and BOP costs }\end{array}$ & \\
\hline
\end{tabular}

Table 2: Analysis of the strengths and weaknesses of CPV.

${ }^{1}$ See e.g.: http://cpvconsortium.org/pdfs/press_releases/CPV_Environmental\%20Report_07-09-11.pdf, http://www.seas.columbia.edu/clca/Task12_LCl_LCA_10_21_Final_Report.pdf

\begin{tabular}{lllll}
\hline Fraunhofer ISE | NREL & CPV Report 1.1 & December 2015 & TP-5J00-65130 & 9 |25
\end{tabular}




\section{$2.1 \quad$ Status}

\subsubsection{Status of the Industry}

Since 2011, many CPV companies have closed, entered bankruptcy, shifted away from CPV to standard PV, or been acquired by larger firms, some of which continue to pursue CPV while others do not. This type of consolidation is typical of early stage industries. Table 6 and Table 7 give information on the companies that remain open and appear to continue working on HCPV or LCPV modules.

The main challenge cited by the industry is the difficulty of CPV to compete with flat-plate cSi PV modules on cost, in light of the recent drop in c-Si module prices due to the significant advantage in manufacturing scale that flat-plate currently has over CPV. CPV companies expect that this technology can compete on an LCOE basis with flat-plate PV when installed in sunny areas, but the road to scale has been difficult.

While a breadth of designs in the CPV space exist, the majority of companies are HCPV and most of those employ Fresnel primary lenses in refractive, point-focus systems. Some companies have moved towards smaller cells and higher concentrations in hopes of reducing costs and thermal management requirements. In fact, Table 6 in the appendix shows that almost all HCPV companies now operate near 500x or 1000x. In LCPV, both the designs and concentration ratios shown in Table 7 tend to be much more varied than in HCPV, with groups even targeting building integrated CPV (BICPV) and modules floating on the water.

Despite this convergence within HCPV onto similar module designs, and the recent availability of some standard components, firms continue to use their own custom components. Although many optics suppliers remain enthusiastic about the promise of CPV and the potential for standardized components to help ease growing pains within the industry, there is concern about the existence of a stable market in the future.

Several major blows to formerly leading CPV companies have occurred very recently, shaking confidence in the industry. In 2012, Amonix, now Arzon Solar, closed its $150 \mathrm{MW}$ manufacturing plant in Las Vegas; in 2013, SolFocus, a supplier of systems with a Cassegrain optics, underwent liquidation. In 2014, Soitec was dropped from plans for a $150 \mathrm{MW}$ power plant in the Imperial Valley, California, with the developer opting to use conventional PV modules in its installation. Very recently in August 2015, Soitec announced that the deal to sell its solar system business failed ${ }^{1}$. This means that they will not produce CPV modules anymore. Moreover, Suncore the major Chinese manufacturer also is stopping the CPV module production and is defining a new strategy. It is still unclear how large of an impact these events will have on the CPV industry as a whole.

Anyhow, several companies making III-V multi-junction cells that can be used in terrestrial CPV applications are active, and continue to improve their products, as noted in Section 3. In addition, the total amount of installed CPV has grown significantly since 2011, as can be seen in Figure 2, and large deals, like SunPower's plan to install $40 \mathrm{MW}$ in China and $120 \mathrm{MW}$ of

1 http://www.soitec.com/en/news/press-releases/soitec-announces-the-end-of-negotiations-with-concensolarregarding-a-sale-of-solar-assets-and-continues-its-refocus-on-electronics-1772/

\begin{tabular}{llll}
\hline Fraunhofer ISE | NREL & CPV Report 1.1 & December 2015 & TP-5J00-65130
\end{tabular}


LCPV in Inner Mongolia, are still being made ${ }^{1}$. Soitec continues to install power plants in South Africa, China and the United States. Suncore has installed $140 \mathrm{MWp}$ at Goldmud, China. Manufacturing capacities are available to produce HCPV systems, e.g. $300 \mathrm{MW} / \mathrm{a}$ at Suncore. The future of the existing capacity of $380 \mathrm{MW} / \mathrm{a}$ at Soitec is currently unclear. Trackers have also made great strides in recent years, being both more reliable and lowercost than in the past.

\subsubsection{Installations and Projects}

CPV has only begun to be established in the market in recent years (see Figure 2). A list of CPV power plants with MW capacities can be found in Table 4 in the appendix. The CPVconsortium recently started to collect data on such plants, see: http://cpvconsortium.org/projects. The first power plant exceeding the $1 \mathrm{MW}$-level was installed in Spain in 2006. Since then, an increasing number of commercial power plants have been installed in the MW range annually, with several exceeding $20 \mathrm{MW}$ peak capacity (Figure 3). The largest share, more than $90 \%$ of the capacity installed to date, is in the form of HCPV with two-axis tracking. HCPV systems were mostly equipped with c-Si concentrator cells before 2008, but III-V multi-junction solar cells have since become standard. LCPV systems still employ either slightly modified standard or high-efficiency c-Si cells.

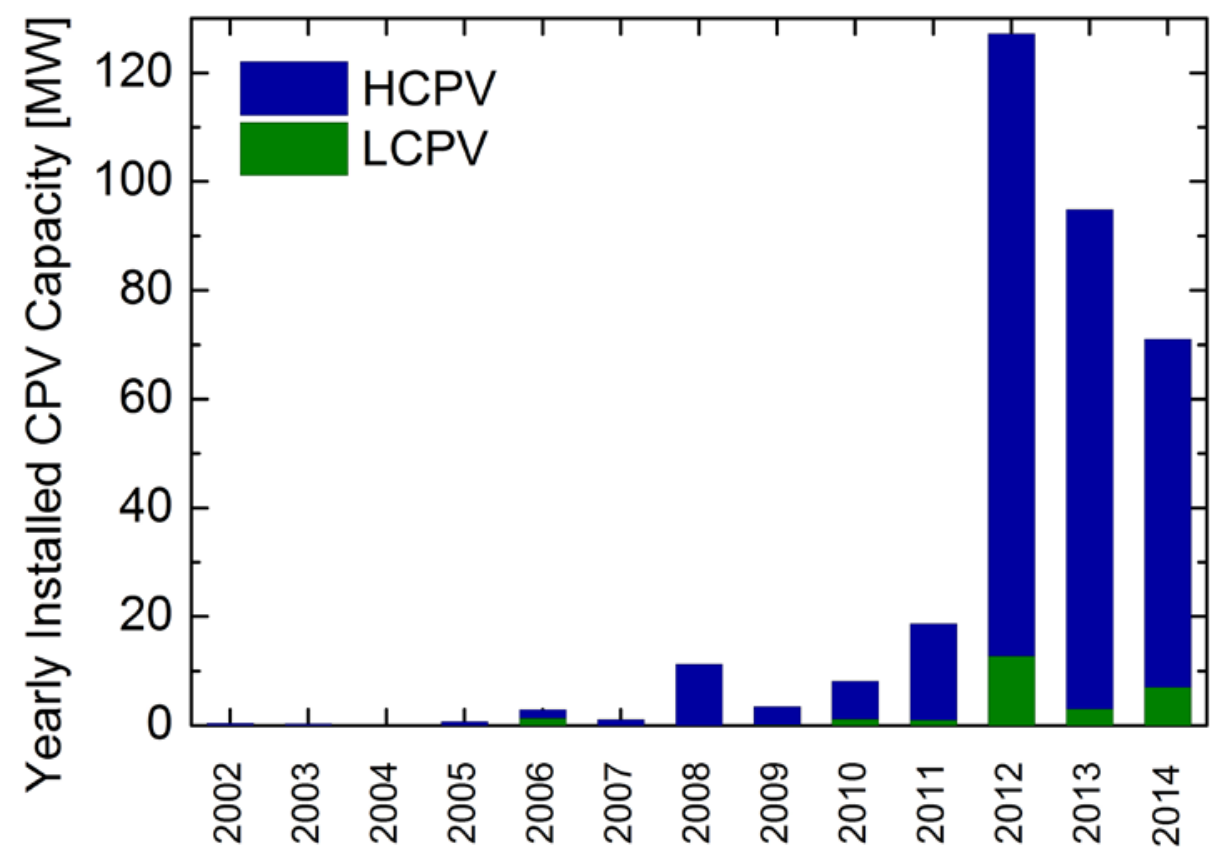

Figure 2: CPV capacity installed each year with indication of the type (HCPV or LCPV), globally, as derived from public announcements.

Along with the trend toward larger power plants, there is a noticeable regional diversification of the market (Figure 4). While the first large power plants were installed solely in Spain, > $1 \mathrm{MW}$ CPV power plants have also been completed in several other countries since 2010. Current regional key areas include the United States, China, Australia, and South Africa.

\footnotetext{
${ }^{1}$ Sunpower press release of April 16, 2015. http://newsroom.sunpower.com/2015-04-16-SunPowers-China-JointVenture-Partners-with-Apple-to-Provide-Solar-Power-to-the-Environmentally-Preserved-ABA-Region
} 
Compared to conventional PV, the CPV market is still small, with a market volume around 70 MWp in 2014. For 2015 a total number of new installations between 10 and $25 \mathrm{MWp}$ is estimated.
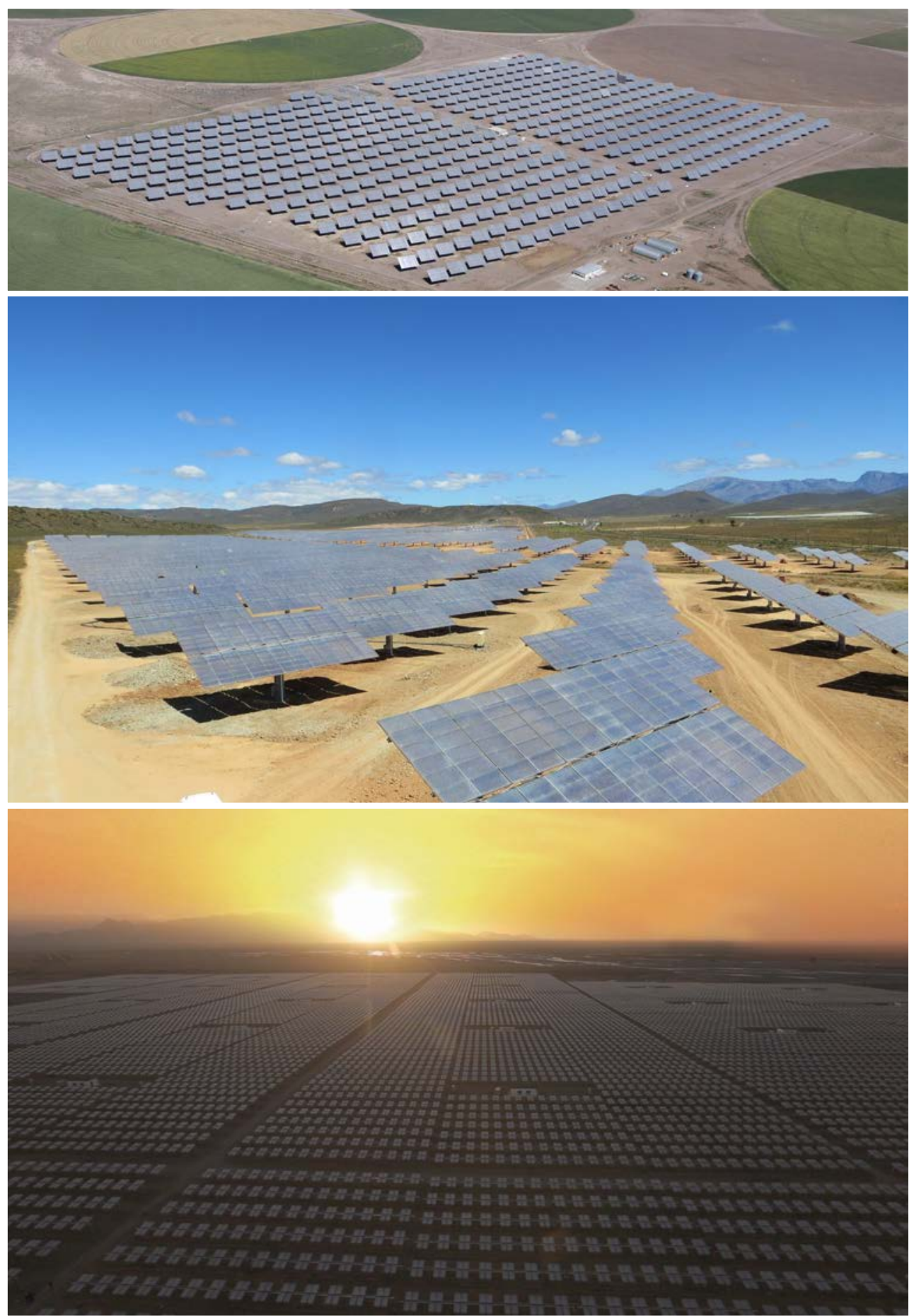

Figure 3: Examples of large CPV power plants. From top to bottom: $30 \mathrm{MW}$ plant in Alamosa, Colorado, USA (๑ Amonix); 44 MW in Touwsrivier, South Africa (๑ Soitec); 140 MW in Golmud, China (๑ Suncore). 


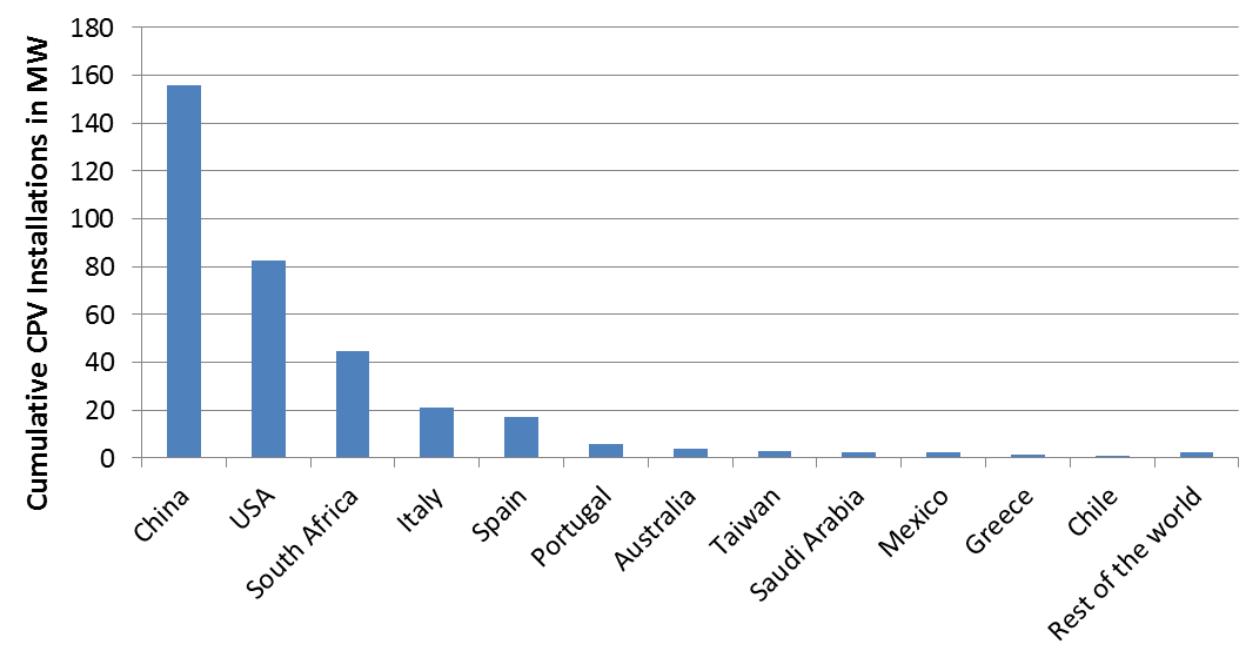

Figure 4: Grid-connected CPV capacity by country through end of July 2015. All countries with a total installation of $1 \mathrm{MWp}$ or more are shown separately.

\subsubsection{Standards}

As with standard PV systems, CPV installations are typically warranted for at least 25 years, thus they have to be reliable. The standard IEC 62108 called "Concentrator photovoltaic (CPV) modules and assemblies - Design qualification and type approval" issued by the International Electrotechnical Commission (IEC) in 2007 is a mandatory step to enter the market. Today many companies have certified their products according to this standard. Please note that additional UL and IEC standards (e.g. for power and energy rating, module safety, tracker, optics, cell assembly) have been published or are under preparation.

\subsection{Perspective}

\subsubsection{System Costs and Levelized Cost of Electricity}

Market prices and cost data for CPV systems are difficult to obtain. This originates from the young market and the comparably low number of installations and companies active in the field. Hence a learning curve is not yet reliable and an analysis of system cost and levelized cost of electricity (LCOE) will include a rather high uncertainty until CPV reaches a high deployment volume.

At the end of 2013 Fraunhofer ISE published an extensive study on the LCOE of renewable energy systems [5]. The study includes also CPV systems. For details about the assumptions made we refer to the publically available study. Recently a group from the University of Ottawa also published gathered data on cost and LCOE for CPV [9].

Based on an industry survey and literature, CPV system prices, including installation for CPV power plants with a capacity of $10 \mathrm{MW}$, were identified to lie between $€ 1400 / \mathrm{kWp}$ and $€ 2200 / \mathrm{kWp}$. The large range of prices results from the different technological concepts as well as the nascent and regionally variable markets. Using technical and financial assumptions specified in [5], the calculations result in LCOE values for CPV power plants from $€ 0.10 / \mathrm{kWh}$ to $€ 0.15 / \mathrm{kWh}$ at locations with a DNI of $2000 \mathrm{kWh} /\left(\mathrm{m}^{2} \mathrm{a}\right)$ and $€ 0.08 / \mathrm{kWh}$ to $€ 0.12 / \mathrm{kWh}$ with $2500 \mathrm{kWh} /\left(\mathrm{m}^{2} \mathrm{a}\right)$ (Figure 5).

\begin{tabular}{llll}
\hline Fraunhofer ISE | NREL & CPV Report 1.1 & December 2015 & TP-5J00-65130
\end{tabular}


For CPV, there are still great uncertainties today concerning the future market development and thus also the possibility of achieving additional cost reductions through technological development. The analysis, however, shows that CPV has potential for reducing the LCOE, which encourages a continued development of this technology. If installations continue to grow through 2030, CPV could reach a cost ranging between $€ 0.045 / \mathrm{kWh}$ and $€ 0.075 / \mathrm{kWh}$ (Figure 6). The system prices, including installation for CPV power plants would then be between $€ 700$ and $€ 1100 / \mathrm{kWp}$.

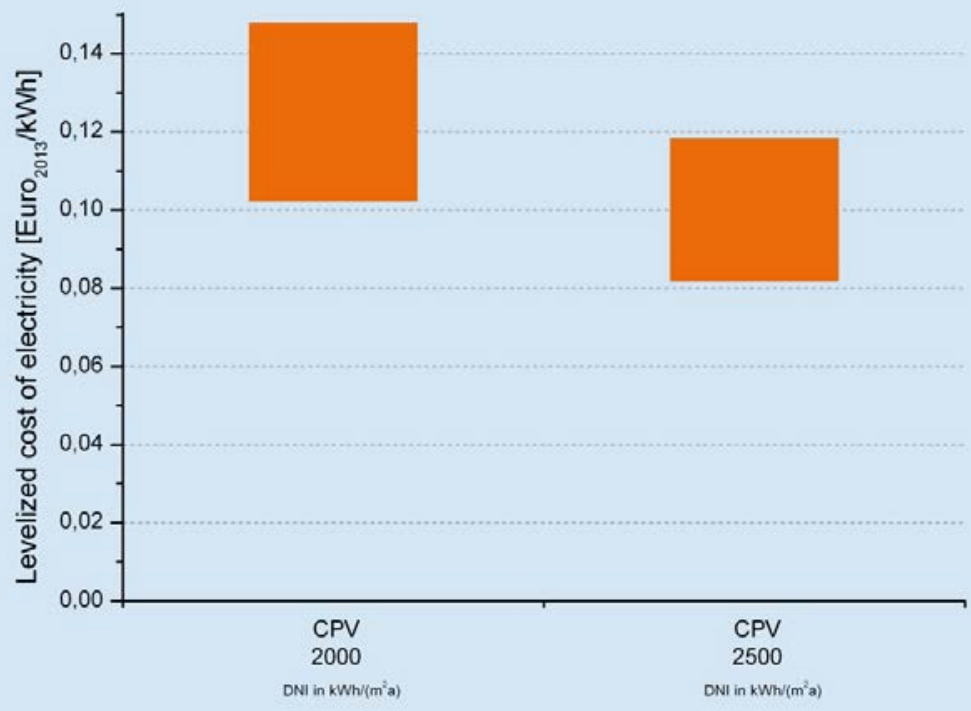

Figure 5: Levelized cost of electricity (LCOE) of CPV systems under high solar irradiation (DNI) of 2000 $\mathrm{kWh} /\left(\mathrm{m}^{2} \mathrm{a}\right)$ and $2500 \mathrm{kWh} /\left(\mathrm{m}^{2} \mathrm{a}\right)$ in 2013. Source: [5]

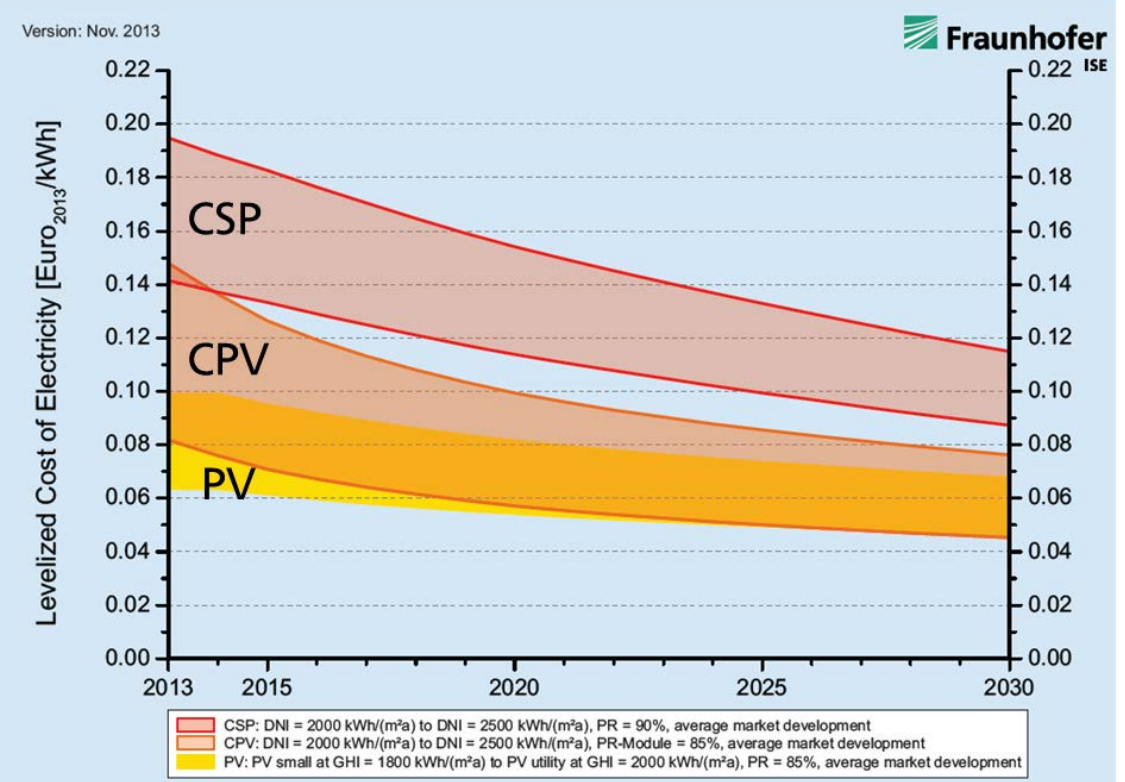

Figure 6: Development of the LCOE of PV, CSP and CPV plants at locations with high solar irradiation of $2000 \mathrm{kWh} /\left(\mathrm{m}^{2} \mathrm{a}\right)-2500 \mathrm{kWh} /\left(\mathrm{m}^{2} \mathrm{a}\right)$. Source: [5]. 
High efficiency is one of the key drivers to make HCPV more cost-competitive on the LCOE level. Hence the majority of efforts in research aim at increasing the efficiency at all levels from cell to module to system. Figure 7 shows the increase in efficiency since 2000 and underlines the progress made by research and development efforts. The trend lines are based on the expectations of the European Photovoltaic Technology Platform in 2011 [7]. Significant potential for even higher efficiencies than today is foreseen. This chapter aims at summarizing corresponding developments in CPV research and technology in recent years that could lead to additional improvements in efficiency.

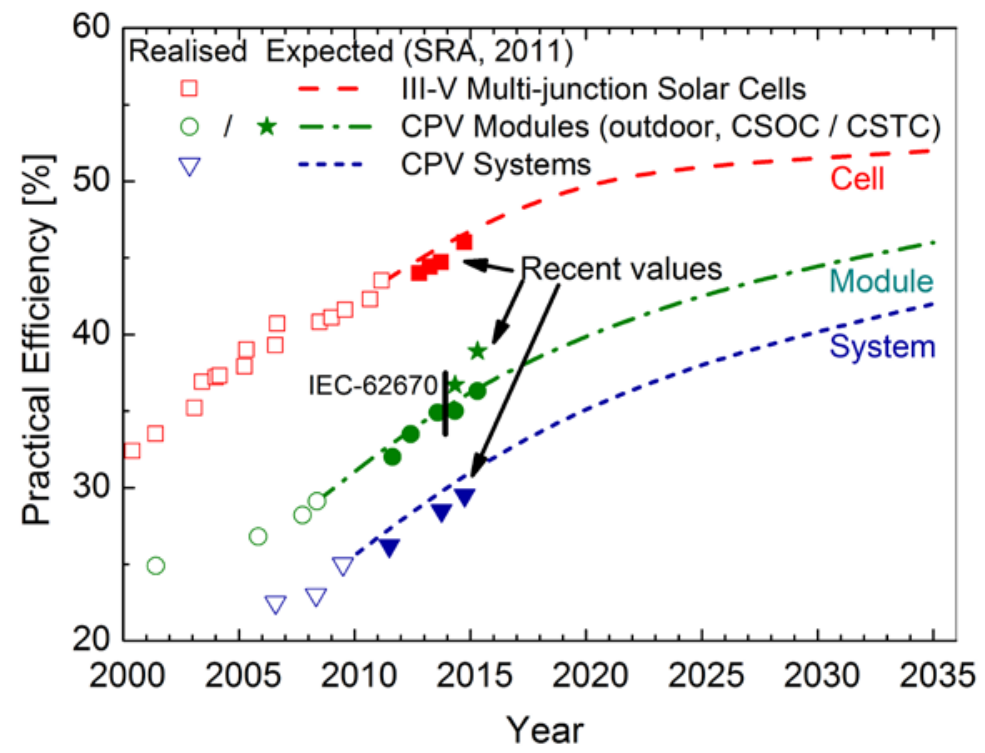

Figure 7: Development of record efficiencies of III-V multi-junction solar cells and CPV modules (cells: $\mathrm{X}^{*} \mathrm{AM} 1.5 \mathrm{~d}$; modules: outdoor measurements). Progress in top-of-the-line CPV system efficiencies is also indicated. (AM1.5d lab records according to Green et al., Solar Cell Efficiency Tables from 1993 [10] to 2015 [3]; CPV module and system efficiencies collected from various publications ${ }^{1}$ ). The trend lines show expected efficiencies from the Strategic Research Agenda (SRA) developed by the European Photovoltaics Technology Platform in 2011 [7]. Recent efficiency values (full symbols) follow the trend very well.

\subsection{Solar Cell Efficiency Status}

The efficiency of III-V multi-junction solar cells is the key driver to lower the LCOE of energy produced by HCPV technology. In Figure 8, record efficiencies for these solar cells are displayed. Since 2002 the efficiency has increased by $0.9 \%$ absolute per year. Solar cells made by Sharp [11] and Fraunhofer ISE [2] achieved today's champion efficiencies of $44.4 \%$

${ }^{1}$ CPV module efficiencies until 2014 refer to prevailing ambient conditions outdoors. Since 2014 measurements under IEC 62670-1 reference conditions following the current IEC power rating draft 62670-3 are shown. The IECnorm IEC 62670-1 defines two standard conditions for CPV modules. Concentrator Standard Test Conditions (CSTC) which means DNI of $1000 \mathrm{~W} / \mathrm{m}^{2}, 25^{\circ} \mathrm{C}$ cell temperature and AM1.5d spectral irradiance and Concentrator Standard Operating Conditions (CSOC) which means DNI of 900 $\mathrm{W} / \mathrm{m}^{2}, 20^{\circ} \mathrm{C}$ ambient temperature and $\mathrm{AM} 1.5 \mathrm{~d}$ spectral irradiance.

\begin{tabular}{llll}
\hline Fraunhofer ISE | NREL & CPV Report 1.1 & December 2015 & TP-5J00-65130
\end{tabular}


and $46.0 \%$ for triple- and four-junction solar cells, respectively. As can be seen in Figure 8 , commercial cell efficiencies follow R\&D results very quickly, indicating that new research in III-Vs is quickly adopted into the production. According to product data sheets of the companies, today multi-junction solar cells are commercially available with efficiencies between $38 \%$ and $43 \%$. Table 5 in the appendix lists companies with the ability to produce III-V multi-junction solar cells for HCPV.

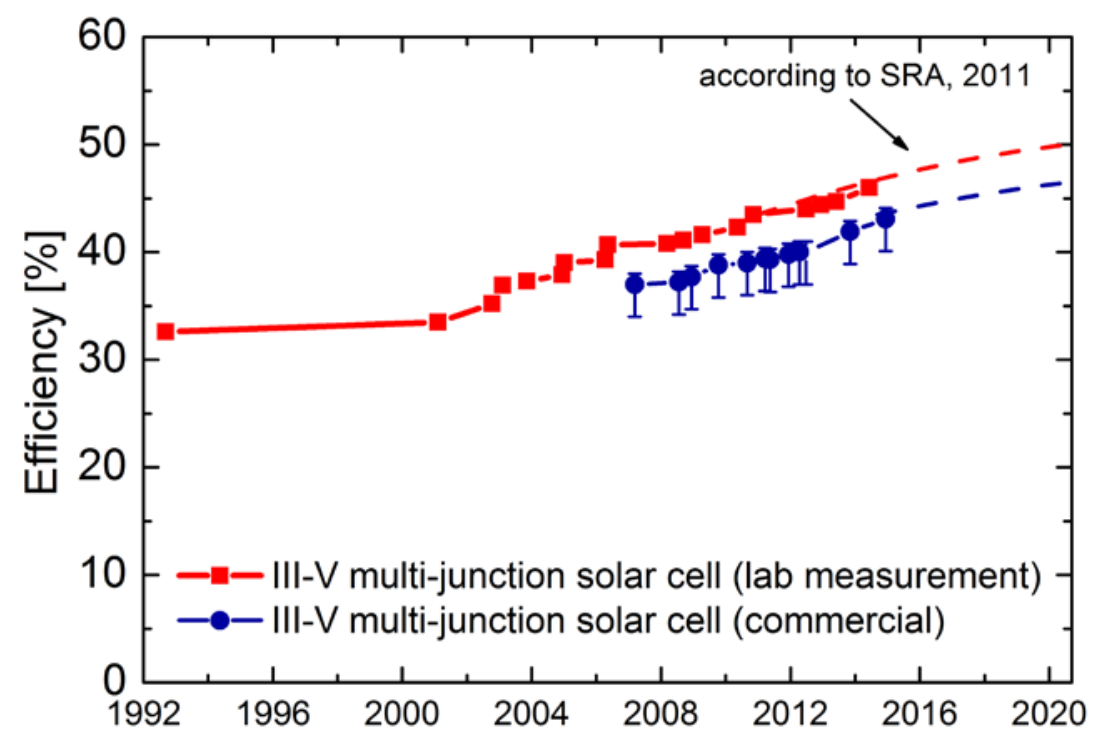

Figure 8: Development of record efficiencies of III-V multi-junction solar cells under concentrated light ( $\left.x^{*} A M 1.5 d\right)$. Examples for average commercial concentrator cell efficiencies (different concentration levels) are also indicated. (AM1.5d lab records according to Green et al., Solar Cell Efficiency Tables from 1993 [10] to 2015 [3] ; AM1.5d commercial efficiencies averaged from company product sheets). The trend lines show expected efficiencies from the Strategic Research Agenda (SRA) developed by the European Photovoltaics Technology Platform in 2011 [7].

There are several main reasons why III-V multi-junction solar cells reach the highest efficiencies of any photovoltaic technology. III-V solar cells are composed of compounds of elements from groups III and $V$ of the periodic table. In the corresponding multi-junction devices, several solar cells made of different III-V semiconductors are stacked with decreasing bandgaps from top to bottom. This reduces thermalisation losses as phometric tons are mostly absorbed in layers with a bandgap close to the photon's energy. Moreover, transmission losses are reduced as the absorption range of the multi-junction solar cell is usually wider than for single-junction devices. Finally the use of direct bandgap III-V semiconductors facilitates a high absorption of light even in comparably thin layers.

The most common III-V multi-junction solar cell in space and terrestrial concentrator systems is a lattice-matched $\mathrm{Ga}_{0.50} \mathrm{In}_{0.50} \mathrm{P} / \mathrm{Ga}_{0.99} \mathrm{In}_{0.01} \mathrm{As} / \mathrm{Ge}$ triple-junction solar cell. The device is grown with high throughput in commercial metal-organic vapor phase epitaxy (MOVPE) reactors. All semiconductors in this structure have the same lattice constant as the Ge substrate, which facilitates crystal growth with high material quality. However, its bandgap combination is not optimal as the bottom cell receives significantly more light than the upper two cells resulting in about twice the photocurrent of the upper two subcells. Nevertheless, as record efficiency for this triple-junction concentrator solar cell $41.6 \%$ (AM1.5d, 364 suns) has been achieved in 2009 [12]. Various approaches are under investigation to further increase in solar cell efficiencies. Table 3 presents cell architectures that have achieved record cell efficiencies above $41 \%$. These use different elements from the wide range of technology building blocks available for III-V multi-junction solar cells. A detailed discussion of each cell structure is out of scope of this paper. A more detailed overview can, for example, be found in References [13-15].

\begin{tabular}{lllll|l}
\hline Fraunhofer ISE | NREL & CPV Report 1.1 & December 2015 & TP-5J00-65130 & 16 | 25
\end{tabular}

Fraunhofer ISE is a member of the Fraunhofer-Gesellschaft, Europe's largest application-oriented research organization. 


\begin{tabular}{|c|c|c|c|}
\hline Cell Architecture & $\begin{array}{l}\text { Record } \\
\text { Efficiency } \\
\text { (Accredited test } \\
\text { lab) }\end{array}$ & Institution & Comments \\
\hline $\begin{array}{l}\text { GalnP/GaAs//GalnAsP/GalnAs } \\
{[3,16]}\end{array}$ & $\begin{array}{l}46.0 @ 508 \text { suns } \\
\text { (AIST) }\end{array}$ & $\begin{array}{l}\text { Fraunhofer } \\
\text { ISE/ Soitec/ } \\
\text { CEA }\end{array}$ & $\begin{array}{l}\text { 4J, wafer bonding, lattice } \\
\text { matched grown on GaAs } \\
\text { and InP }\end{array}$ \\
\hline $\begin{array}{l}\text { GalnP/GaAs/GalnAs/GalnAs } \\
{[17,18]}\end{array}$ & $\begin{array}{l}45.7 \% @ 234 \\
\text { suns (NREL) }\end{array}$ & NREL & 4J, inverted metamorphic \\
\hline GalnP/GaAs/GalnAs [11] & $\begin{array}{l}44.4 @ 302 \text { suns } \\
\text { (Fraunhofer ISE) }\end{array}$ & Sharp & 3J, inverted metamorphic \\
\hline GalnP/GaAs/GalnNAs [19] & $\begin{array}{l}\text { 44.0\%@942 } \\
\text { suns (NREL) }\end{array}$ & $\begin{array}{l}\text { Solar } \\
\text { Junction }\end{array}$ & $\begin{array}{l}\text { 3J, MBE, lattice matched, } \\
\text { dilute nitrides, grown on } \\
\text { GaAs }\end{array}$ \\
\hline \multirow{2}{*}{ GalnP/Ga(In)As/GalnAs [20,21] } & $\begin{array}{l}42.6 \% @ 327 \\
\text { suns (NREL) } \\
\text { (40.9\% @ } 1093 \\
\text { suns) }\end{array}$ & NREL & \multirow{2}{*}{ 3J, inverted metamorphic } \\
\hline & $\begin{array}{l}42.4 \% @ 325 \\
\text { suns (NREL) } \\
\text { (41\% @ } 1000 \\
\text { suns) }\end{array}$ & Emcore & \\
\hline GalnP-GaAs-wafer-GalnAs [22] & $\begin{array}{l}42.3 \% @ 406 \\
\text { suns (NREL) }\end{array}$ & Spire & $\begin{array}{l}\text { 3J, epi growth lattice } \\
\text { matched on front and } \\
\text { inverted metamorphic on } \\
\text { back of GaAs wafer }\end{array}$ \\
\hline GalnP-Ga(In)As-Ge [12] & $\begin{array}{l}41.6 \% @ 364 \\
\text { suns } \\
\text { (NREL) }\end{array}$ & Spectrolab & $\begin{array}{l}\text { 3J, lattice matched, } \\
\text { commercially available; }\end{array}$ \\
\hline GalnP-GalnAs-Ge [23] & $\begin{array}{l}41.1 \% @ 454 \\
\text { suns (Fraunhofer } \\
\text { ISE) }\end{array}$ & $\begin{array}{l}\text { Fraunhofer } \\
\text { ISE }\end{array}$ & $\begin{array}{l}\text { 3J, upright metamorphic; } \\
\text { commercially available } \\
\text { from AZUR SPACE, } \\
\text { Spectrolab }\end{array}$ \\
\hline
\end{tabular}

Table 3: Summary of record concentrator cell efficiencies above $41 \%$ based on III-V multi-junction solar cells.

Note that LCPV systems mainly use c-Si solar cells. As this report mainly focuses on the HCPV approach, these solar cells are not described in detail here.

\subsection{Material Availability}

Gallium (Ga), indium (In), and germanium (Ge) are usually employed in current designs for III-V multi-junction cells employed in CPV, and have limited global supplies. The total estimated annual production of Ga and In from byproduct recovery, the primary means of mining these elements, was 280 metric tons and 770 metric tons respectively in 2013 [24]. Current annual production of Germanium in 2011 was estimated at 118 metric tons [25]. These numbers include production of virgin materials only, and not any reclaimed or preconsumer recycled materials, which are also available.

Assuming a 200 micron thick Ge wafer, about $0.1 \mathrm{~g} / \mathrm{cm}^{2}$ are required if no kerf or dicing losses are assumed. For $30 \%$ yield (due to kerf loss, dicing losses, and breakage), about 0.4 $\mathrm{g} / \mathrm{cm}^{2}$ of $\mathrm{Ge}$ is required. The true Ge requirement lies somewhere in the middle of these two numbers, depending on how effectively a given company is able to recycle the kerf. Most

\begin{tabular}{llll}
\hline Fraunhofer ISE | NREL & CPV Report 1.1 & December 2015 & TP-5J00-65130
\end{tabular}


companies are able to recycle the majority of the kerf and other material such that total losses are only a few percent. Thus, we would expect less than 4 metric tons of Ge would be required for $1 \mathrm{GW}$ production, assuming 30\% module efficiency and 1,000x concentration. The maximum requirement would be approximately 12 metric tons if no material was recycled. The material requirement decreases with increases in efficiency and concentration. It is possible to supply this level of demand with the current production capacity of Ge, but demand from other industries will also significantly impact the supply of Ge available for CPV [25]. Outside of solar, Ge is used for electronics, infrared optics, fiber optics, and polyethylene terephthalate (PET) catalysts. Solar and electronics constitute the fastest growing demand. Therefore, Ge production may need to be expanded in order to support deployment of these cells at large scales. The total worldwide Ge resources are estimated at 35,600 metric tons, with 24,600 metric tons from coal and the rest from lead/zinc, and, thus, is not a limiting factor in expanding production. However, Ge is currently produced as a byproduct of zinc and coal, which have much larger markets and constitute the core focus of most companies mining Ge. It is unclear how much the price of germanium must rise to encourage expansion of Ge production and how much can be produced as a byproduct at prices that do not impair the economics of III-V multi-junction cells employing germanium.

The amount of Ga and In required for a typical III-V multi-junction cell grown on Ge is very small, and is not expected to require an expansion of the supply chain to achieve GW annual production volumes. In addition, the thicknesses of the base layers may be reduced in future designs, further reducing Ga and In material requirements.

For metamorphic or inverted metamorphic cells, the Ga and In used in the MOVPE layers is currently significantly higher than for the lattice matched design on Ge since a thick graded buffer layer, usually GalnP, is required and a GalnAs cell is often employed. However, the total amount used at high concentrations is still very low and not expected to require supply chain expansion at GW annual production for HCPV. The GaAs substrate, however, can represent more significant Ga use if it is not reused. For single-use, 600 micron thick GaAs substrates, less than $0.2 \mathrm{~g} / \mathrm{cm}^{2}$ are required assuming $100 \%$ yield. If we again assume $30 \%$ yield and no recycling, approximately $0.5 \mathrm{~g} / \mathrm{cm}^{2}$ of $\mathrm{Ga}$ is required. We expect the substrate will require less than 5.5 metric tons for $1 \mathrm{GW}$ of production for the case of $30 \%$ module efficiency and 1,000x concentration with an effective recycling program. Even without any recycling, no more than 17 metric tons would be required in this case. While this is significant, this still currently represents only about $6 \%$ of the overall annual supply.

Material availability of Ga, In, and Ge for III-V multi-junction cells would be a much more significant challenge if the cells are used for low concentration or one sun applications.

\section{Acknowledgements}

We are grateful to many individuals who have contributed to this report. Special thanks go to the III-V group at Fraunhofer ISE, Dan Friedman, Hansjörg Lerchenmüller, Michael Yates and Karlynn Cory. This work was supported in part by the U.S. Department of Energy under Contract No. DE-AC36-08-G028308 with the National Renewable Energy Laboratory. 
[1] T. Gerstmaier, M. Röttger, T. Zech, R. Moretta, C. Braun, et al., Five Years of CPV Field Data: Results of a Long-term Outdoor Performance Study, in: Proceedings of the 10th International Conference on Concentrating Photovoltaic Systems, (Albuquerque, NM, USA, 2014).

[2] Fraunhofer ISE, New world record for solar cell efficiency at 46\%, http://www.ise.fraunhofer.de/en/press-and-media/press-releases/pressreleases-2014/new-world-record-for-solar-cell-efficiency-at-46-percent (2014).

[3] M. A. Green, K. Emery, Y. Hishikawa, W. Warta, E. D. Dunlop, Solar cell efficiency tables (Version 45), Progress in Photovoltaics: Research and Applications 23(1), 1-9 (2015).

[4] Soitec, Four-junction solar cell developped using Soitec's expertise in semiconductor materials sets new efficiency record of $38.9 \%$ for CPV module, http://www.soitec.com/en/news/press-releases/article-1737 (2015).

[5] Fraunhofer ISE, Levelized Cost of Electricity - Renewable Energy Technologies, www.ise.fraunhofer.de/de/veroeffentlichungen/veroeffentlichungenpdf-dateien/studien-und-konzeptpapiere/studie-stromgestehungskostenerneuerbare-energien.pdf (2013).

[6] R. Angel, T. Stalcup, B. Wheelwright, S. Warner, K. Hammera, et al., Shaping solar concentrator mirrors by radiative heating in: Proceedings of SPIE 9175, High and Low Concentrator Systems for Solar Energy Applications IX, (San Diego, California, USA, 2014).

[7] European Photovoltaic Technology Platform, A Strategic Research Agenda for Photovoltaic Solar Energy Technology, Edition 2, www.eupvplatform.org/publications/strategic-research-agenda-implementationplan.html (2011).

[8] P. Pérez-Higuerasa, E. Muñoz, G. Almonacida, P. G. Vidala, High concentrator photovoltaics efficiencies: Present status and forecast, Renewable and Sustainable Energy Reviews 15(4), 1810-1815 (2011).

[9] J. E. Haysom, O. Jafarieh, H. Anis, K. Hinzer, D. Wright, Learning curve analysis of concentrated photovoltaic systems, Progress in Photovoltaics: Research and Applications, in press (2014).

[10] M. A. Green, K. Emery, D. L. King, S. Igari, W. Warta, Solar Cell Efficiency Tables (Version 01), Progress in Photovoltaics: Research and Applications 12(1), 55-62 (1993).

[11] K. Sasaki, T. Agui, K. Nakaido, N. Takahashi, R. Onitsuka, et al., Development of InGaP/GaAs/InGaAs inverted triple junction concentrator solar cells, in: Proceedings of the 9th International Conference on Concentrator Photovoltaic Systems, 22-25 (Miyazaki, Japan, 2013).

[12] R. King, A. Boca, W. Hong, D. Larrabee, K. M. Edmondson, et al., Band-gapengineered architectures for high-efficiency multijunction concentrator solar cells, in: Proceedings of the 24th European Photovoltaic Solar Energy Conference and Exhibition, 55-61 (Hamburg, Germany, 2009).

[13] S. P. Philipps, A. W. Bett, III-V multi-junction solar cells, in Advanced Concepts in Photovoltaics, edited by A. J. Nozik, G. Conibeer, and M. C. Beard, 87-117 (The Royal Society of Chemistry, Cambridge, UK, 2014).

[14] D. J. Friedman, J. M. Olson, S. Kurtz, High-efficiency III-V multijunction solar cells, in Handbook of Photovoltaic Science and Engineering, 2nd ed., edited by A. Luque and S. Hegedus, 314-364 (John Wiley \& Sons, West Sussex, UK, 2011).

[15] A. Luque, Will we exceed $50 \%$ efficiency in photovoltaics?, Journal of Applied Physics 110(3), 031301-1-19 (2011).

[16] F. Dimroth, M. Grave, P. Beutel, U. Fiedeler, C. Karcher, et al., Wafer bonded fourjunction GalnP/GaAs//GalnAsP/GalnAs concentrator solar cells with $44.7 \%$

\begin{tabular}{llll}
\hline Fraunhofer ISE | NREL & CPV Report 1.1 & December 2015 & TP-5J00-65130 | 25
\end{tabular}


efficiency, Progress in Photovoltaics: Research and Applications 22(3), 277-82 (2014).

[17] R. M. France, J. F. Geisz, I. Garcla, M. A. Steiner, W. E. McMahon, et al., QuadrupleJunction Inverted Metamorphic Concentrator Devices, IEEE Journal of Photovoltaics 5(1), 432 - 437 (2015).

[18] NREL, NREL Demonstrates 45.7\% Efficiency for Concentrator Solar Cell, News Release NR-4514, http://www.nrel.gov/news/press/2014/15436.html (2014).

[19] V. Sabnis, H. Yuen, M. Wiemer, High-efficiency multijunction solar cells employing dilute nitrides, in: Proceedings of the 8th International Conference on Concentrating Photovoltaic Systems, 14-19 (Toledo, Spain, 2012).

[20] J. F. Geisz, A. Duda, R. M. France, D. J. Friedman, I. Garcia, et al., Optimization of 3junction inverted metamorphic solar cells for high-temperature and highconcentration operation, in: 8th International Conference on Concentrating Photovoltaic Systems, 44-48 (Toledo, Spain, 2012).

[21] D. Aiken, E. Dons, N. Miller, F. Newman, P. Patel, et al., Commercial concentrator cell results and record IMM solar cell efficiency, in: 8th International Conference on Concentrating Photovoltaic Systems, 44-48 (Toledo, Spain, 2012).

[22] P. Chiu, S. Wojtczuk, C. Harris, D. Pulver, M. Timmons, $42.3 \%$ efficient InGaP/GaAs/InGaAs concentrators using bifacial epigrowth, in: 37th IEEE Photovoltaic Specialists Conference, 771-774 (Seattle, Washington, USA, 2011).

[23] W. Guter, J. Schöne, S. P. Philipps, M. Steiner, G. Siefer, et al., Current-matched triple-junction solar cell reaching $41.1 \%$ conversion efficiency under concentrated sunlight, Applied Physics Letters 94(22), 223504-1-6 (2009).

[24] M. Woodhouse, A. Goodrich, R. Margolis, T. L. James, M. Lokanc, et al., SupplyChain Dynamics of Tellurium, Indium, and Gallium Within the Context of PV Manufacturing Costs, IEEE Journal of Photovoltaics 3(2), 833-837 (2013).

[25] O. Collins, Study of By-Products of Copper, Lead, Zinc, and Nickel, Technical Report prepared for the International Lead and Zinc Study Group, the International Nickel Study Group, and the International Copper Study Group,(2012). 


\subsection{Data}

Data on CPV installations and manufacturing are presented that were collected through the end of July 2015. We are happy to receive comments and additions (simon.philipps@ise.fraunhofer.de).

\subsubsection{CPV Power Plants}

Table 4 lists all CPV power plants with a capacity of $1 \mathrm{MW}$ or more. Only plants with confirmed completed installation are shown. Plants that are listed in the project library of the CPV Consortium (http://cpvconsortium.org/projects) are marked with an asterisk at the end of the online year. Data for these plants are mostly collected from public presentations, press releases, or website announcements.

\begin{tabular}{|c|c|c|c|c|c|c|}
\hline Company & $\begin{array}{l}\text { Origin } \\
\text { Company }\end{array}$ & $\begin{array}{l}\text { Power } \\
\text { in } \mathrm{MW}\end{array}$ & Appr. & Country & Location & $\begin{array}{l}\text { Online } \\
\text { year }\end{array}$ \\
\hline Soitec & $\begin{array}{l}\text { France/ } \\
\text { Germany }\end{array}$ & 5.8 & HCPV & China & Hami & $2014 *$ \\
\hline Soitec & $\begin{array}{l}\text { France/ } \\
\text { Germany }\end{array}$ & 44.2 & $\mathrm{HCPV}$ & $\begin{array}{l}\text { South } \\
\text { Africa }\end{array}$ & Touwsrivier & $2014^{*}$ \\
\hline Soitec & $\begin{array}{l}\text { France/ } \\
\text { Germany }\end{array}$ & 9.2 & $\mathrm{HCPV}$ & USA & $\begin{array}{l}\text { Borrego } \\
\text { Springs }\end{array}$ & $2014^{*}$ \\
\hline Soitec & $\begin{array}{l}\text { France/ } \\
\text { Germany }\end{array}$ & 1.3 & $\mathrm{HCPV}$ & Portugal & Alcoutim & $2014^{*}$ \\
\hline $\begin{array}{l}\text { Suncore } \\
\text { Photovoltaic }\end{array}$ & China & 1.3 & $\mathrm{HCPV}$ & Portugal & Evora & $2014^{*}$ \\
\hline Soitec & $\begin{array}{l}\text { France/ } \\
\text { Germany }\end{array}$ & 1.1 & $\mathrm{HCPV}$ & $\begin{array}{l}\text { Saudi } \\
\text { Arabia }\end{array}$ & Tabuk & 2014 \\
\hline $\begin{array}{l}\text { Solar Systems/ } \\
\text { Silex Systems }\end{array}$ & Australia & 1.0 & HCPV & $\begin{array}{l}\text { Saudi } \\
\text { Arabia }\end{array}$ & Nofa & 2014 \\
\hline SunPower & USA & 7.0 & LCPV & USA & Arizona & 2014 \\
\hline $\begin{array}{l}\text { Suncore } \\
\text { Photovoltaic }\end{array}$ & China & 79.8 & $\mathrm{HCPV}$ & China & Goldmud & $2013^{*}$ \\
\hline Soitec & $\begin{array}{l}\text { France/ } \\
\text { Germany }\end{array}$ & 2.6 & HCPV & China & Hami & $2013^{*}$ \\
\hline Solaria & USA & 2.0 & LCPV & Italy & Sardinia & 2013 \\
\hline Soitec & $\begin{array}{l}\text { France/ } \\
\text { Germany }\end{array}$ & 1.7 & $\mathrm{HCPV}$ & USA & $\begin{array}{l}\text { Newberry } \\
\text { Springs }\end{array}$ & $2013^{*}$ \\
\hline $\begin{array}{l}\text { Solar Systems/ } \\
\text { Silex Systems }\end{array}$ & Australia & 1.5 & HCPV & Australia & Mildura & 2013 \\
\hline SolFocus & USA & 1.3 & HCPV & Mexico & Guanajuato & $2013^{*}$ \\
\hline $\begin{array}{l}\text { Suncore } \\
\text { Photovoltaic }\end{array}$ & China & 1.2 & HCPV & USA & Albuquerque & $2013^{*}$ \\
\hline Soitec & $\begin{array}{l}\text { France/ } \\
\text { Germany }\end{array}$ & 1.2 & HCPV & Italy & Saletti & 2013 \\
\hline SunPower & USA & 1.0 & LCPV & USA & Arizona & 2013 \\
\hline SolFocus & USA & 1.0 & LCPV & Mexico & Cerro Prieto & $2012^{*}$ \\
\hline $\begin{array}{l}\text { Suncore } \\
\text { Photovoltaic }\end{array}$ & China & 58.0 & $\mathrm{HCPV}$ & China & Goldmud & $2012^{*}$ \\
\hline
\end{tabular}




\begin{tabular}{|c|c|c|c|c|c|c|}
\hline Company & $\begin{array}{l}\text { Origin } \\
\text { Company }\end{array}$ & $\begin{array}{l}\text { Power } \\
\text { in } \mathrm{MW}\end{array}$ & Appr. & Country & Location & $\begin{array}{l}\text { Online } \\
\text { year }\end{array}$ \\
\hline Amonix & USA & 30.0 & HCPV & USA & Alamosa & $2012^{*}$ \\
\hline Solaria & USA & 4.1 & LCPV & USA & New Mexico & 2012 \\
\hline Magpower & Portugal & 3.0 & $\mathrm{HCPV}$ & Portugal & Estoi & 2012 \\
\hline Solaria & USA & 2.0 & LCPV & Italy & Puglia & 2012 \\
\hline $\begin{array}{l}\text { Arima EcoEnergy } \\
\text { Tech. Corp. }\end{array}$ & Taiwan & 1.7 & HCPV & Taiwan & Linbian & 2012 \\
\hline Soitec & $\begin{array}{l}\text { France/ } \\
\text { Germany }\end{array}$ & 1.2 & $\mathrm{HCPV}$ & Italy & SantaLucia & $2012^{*}$ \\
\hline Soitec & $\begin{array}{l}\text { France/ } \\
\text { Germany }\end{array}$ & 1.2 & HCPV & Italy & Cerignola & 2012 \\
\hline Soitec & $\begin{array}{l}\text { France/ } \\
\text { Germany }\end{array}$ & 1.1 & $\mathrm{HCPV}$ & Italy & Bucci & 2012 \\
\hline Solaria & USA & 1.1 & LCPV & USA & California & 2012 \\
\hline $\begin{array}{l}\text { BEGI (Beijing } \\
\text { General } \\
\text { Industries) }\end{array}$ & China & 1.0 & $\mathrm{HCPV}$ & China & Golmud & 2012 \\
\hline Solaria & USA & 1.0 & LCPV & Italy & Sardinia & 2012 \\
\hline SolFocus & USA & 1.0 & $\mathrm{HCPV}$ & Italy & Lucera & 2012 \\
\hline Amonix & USA & 5.0 & $\mathrm{HCPV}$ & USA & Hatch & 2011 \\
\hline Amonix & USA & 2.0 & $\mathrm{HCPV}$ & USA & Tucson & 2011 \\
\hline SolFocus & USA & 1.6 & $\mathrm{HCPV}$ & USA & Yucaipa & $2011^{*}$ \\
\hline $\begin{array}{l}\text { Suncore } \\
\text { Photovoltaic }\end{array}$ & China & 1.5 & $\mathrm{HCPV}$ & China & Xiamen & 2011 \\
\hline SolFocus & USA & 1.3 & $\mathrm{HCPV}$ & USA & Hanford & $2011^{*}$ \\
\hline SolFocus & USA & 1.3 & $\mathrm{HCPV}$ & Greece & Crete & 2011 \\
\hline SolFocus & USA & 1.3 & $\mathrm{HCPV}$ & USA & Yuma & $2011^{*}$ \\
\hline Greenvolts & USA & 1.0 & $\mathrm{HCPV}$ & USA & Yuma & 2011 \\
\hline SolFocus & USA & 1.0 & $\mathrm{HCPV}$ & Chile & Santiago & 2011 \\
\hline $\begin{array}{l}\text { Suncore } \\
\text { Photovoltaic }\end{array}$ & China & 3.0 & $\mathrm{HCPV}$ & China & Goldmud & 2010 \\
\hline Soitec & $\begin{array}{l}\text { France/ } \\
\text { Germany }\end{array}$ & 1.4 & $\mathrm{HCPV}$ & USA & Questa & 2010 \\
\hline SolFocus & USA & 1.3 & $\mathrm{HCPV}$ & USA & Victorville & $2010^{*}$ \\
\hline Sungrow & China & 1.0 & LCPV & China & Qinghai & 2010 \\
\hline $\begin{array}{l}\text { Amonix/ Guascor } \\
\text { Foton }\end{array}$ & Spain & 2.0 & $\mathrm{HCPV}$ & Spain & Murcia & 2009 \\
\hline $\begin{array}{l}\text { Amonix/Guascor } \\
\text { Foton }\end{array}$ & Spain & 7.8 & $\mathrm{HCPV}$ & Spain & Villafranca & 2008 \\
\hline $\begin{array}{l}\text { Amonix/ Guascor } \\
\text { Foton }\end{array}$ & Spain & 1.5 & HCPV & Spain & Ecija & 2006 \\
\hline Abengoa Solar & Spain & 1.2 & LCPV & Spain & $\begin{array}{l}\text { Sanlúcar La } \\
\text { Mayor }\end{array}$ & 2006 \\
\hline Sungrow & China & 1.0 & LCPV & China & Wuwei, Gansu & Unknown \\
\hline
\end{tabular}

Table 4: Completed CPV power plants with a capacity of $1 \mathrm{MW}$ or more. Power plants marked with an asterisk are listed in the project library of the CPV Consortium (http://cpvconsortium.org/projects). 


\subsubsection{CPV companies for cells and systems}

Table 5 lists companies with the capability for epitaxial growth of III-V multi-junction solar cells. Table 6 presents companies that manufacture HCPV systems and Table 7 those that manufacture LCPV systems. This information changes rapidly. Data were mostly collected from public presentations, press releases, or website announcements through end of November 2014. Note that companies sometimes refrain from posting information about their deployments, and so might have installed capacity even if not listed here.

\begin{tabular}{l|l}
\hline Company & Location \\
\hline Azur Space & Germany \\
\hline \hline CESI & Italy \\
\hline SolAero & \\
\hline (includes Emcore's former photovoltaic business) & USA \\
\hline Microlink Devices & USA \\
\hline Sharp & Japan \\
\hline Solar Junction & USA \\
\hline Spectrolab & USA \\
\hline VPEC & Taiwan \\
\hline Arima & Taiwan \\
\hline Cyrium & Canada \\
\hline Epistar & Taiwan \\
\hline \hline
\end{tabular}

Table 5: Summary of companies with capability for epitaxial growth of III-V multi-junction solar cells. (Companies listed below the bold line (in gray) either seem to have moved away from this approach or do not seem to have production capacities ready for larger quantities, but should not be discounted completely).

\begin{tabular}{l|l|l|l|l}
\hline Company & Location (HQ) & Conc.* & Type of System & $\begin{array}{l}\text { Installed } \\
\text { Capacity } \\
\text { [MWp] }\end{array}$ \\
\hline $\begin{array}{l}\text { Suncore Photovoltaic } \\
\text { Technology }\end{array}$ & Huainan, China & 1,090 & $\begin{array}{l}\text { Lens, tilt and roll } \\
\text { Dish, HCPVT }\end{array}$ & $\begin{array}{l}144.8 \\
<0.1\end{array}$ \\
\hline Soitec & France & 500 & Lens, pedestal & 79.3 \\
\hline Arzon Solar (previously & $\begin{array}{l}\text { Seal Beach, CA, } \\
\text { USA }\end{array}$ & HCPV & Lens, pedestal & 38.4 \\
\hline Amonix) & Bilbao, Spain & HCPV & Lens, pedestal & 12.3 \\
\hline Foton HC (previously: & Victoria, Australia & $\begin{array}{l}500- \\
\text { Solar Systems/Silex }\end{array}$ & $\begin{array}{l}\text { Reflective dish, } \\
\text { dense array, solar } \\
\text { tower }\end{array}$ & 4.3 \\
\hline Systems & $\begin{array}{l}\text { Agualva Cacem, } \\
\text { Portugal }\end{array}$ & HCPV & Lens, pedestal & 4.2 \\
\hline Magpower & $\begin{array}{l}\text { New Taipei City, } \\
\text { Taiwan }\end{array}$ & 476 & Lens, pedestal & 2.1 \\
\hline Arima Ecoenergy & Madrid, Spain & $>1000$ & Lens, pedestal & 0.2 \\
\hline Abengoa Solar & & & & \\
\hline-9
\end{tabular}

${ }^{1}$ AZUR Space also provides solar cell assemblies as OEM products for various CPV technology platforms, e.g. EFA (Enhanced Fresnel Assembly) for concentrator modules with Fresnel optics and ADAM (Advanced Dense Array Module) for the use in parabolic mirror based CPV systems. 


\begin{tabular}{|c|c|c|c|c|}
\hline Company & Location (HQ) & Conc.* & Type of System & \begin{tabular}{|l} 
Installed \\
Capacity \\
[MWp]
\end{tabular} \\
\hline RedSolar & $\begin{array}{l}\text { Zhongshan, } \\
\text { China }\end{array}$ & $\mathrm{HCPV}$ & Lens & 0.2 \\
\hline RayGen & $\begin{array}{l}\text { Blackburn, } \\
\text { Victoria, Australia }\end{array}$ & HCPV & $\begin{array}{l}\text { CSPV: Solar tower } \\
\text { with heliostats }\end{array}$ & 0.2 \\
\hline Sumitomo Electric & Osaka, Japan & HCPV & Lens & 0.1 \\
\hline Renovalia & Madrid, Spain & HCPV & Dish reflector & $<0.1$ \\
\hline Pyron Solar & Vista, CA, USA & 1,200 & Lens, carousel & $<0.1$ \\
\hline Heliotrop & Lyon, France & 1,024 & Lens, pedestal & $<0.1$ \\
\hline Spirox & $\begin{array}{l}\text { Hsinchu City, } \\
\text { Taiwan }\end{array}$ & HCPV & Lens, pedestal & $<0.1$ \\
\hline Airlight Energy & $\begin{array}{l}\text { Biasca, } \\
\text { Switzerland }\end{array}$ & 600 & Reflective dish & \\
\hline Alitec & Navaccio, Italy & $\begin{array}{l}500 \\
1090\end{array}$ & Lens, pedestal & \\
\hline Angelantoni Industrie & Italy & HCPV & Lens, Pedestal & \\
\hline Becar-Beghelli** & Italy & $\mathrm{HCPV}$ & Reflective & \\
\hline BSQ Solar & Madrid, Spain & HCPV & Lens, pedestal & \\
\hline Cool Earth Solar & $\begin{array}{l}\text { Livermore, CA, } \\
\text { USA }\end{array}$ & HCPV & Inflated mirrors & \\
\hline GreenField Solar & $\begin{array}{l}\text { Cleveland, Ohio, } \\
\text { USA }\end{array}$ & HCPV & Reflective & \\
\hline Heliocentric & San Jose, CA & HCPV & $\begin{array}{l}\text { Parabolic, } \\
\text { reflective dish }\end{array}$ & \\
\hline Morgan Solar & $\begin{array}{l}\text { Toronto, ON, } \\
\text { Canada }\end{array}$ & HCPV & $\begin{array}{l}\text { Planar lens, } \\
\text { pedestal }\end{array}$ & \\
\hline Rehnu & Tucson, AZ, USA & HCPV & Dish reflector & \\
\hline Sahaj Solar & Gujarat, India & 500 & Lens, pedestal & \\
\hline Semprius & Durham, NC, USA & $>1,000$ & Microlens & \\
\hline Sharp & Japan & $\mathrm{CPV}$ & Lens, pedestal & \\
\hline$\underline{\text { SolarTron Energy Systems }}$ & $\begin{array}{l}\text { Nova Scotia, } \\
\text { Canada }\end{array}$ & 1,000 & $\begin{array}{l}\text { Reflective dish, } \\
\text { dense array }\end{array}$ & \\
\hline Solergy & $\begin{array}{l}\text { Piedmont, CA, } \\
\text { USA }\end{array}$ & $>500$ & $\begin{array}{l}\text { Cone concentrator. } \\
\text { CPV and CPV + } \\
\text { thermal energy } \\
\text { systems, BICPV }\end{array}$ & \\
\hline Sun Synchrony & Vallejo, CA, USA & HCPV & $\begin{array}{l}\text { Miniaturized } \\
\text { reflectors }\end{array}$ & \\
\hline$\underline{\text { SunCycle }}$ & $\begin{array}{l}\text { Eindhoven, } \\
\text { Netherlands }\end{array}$ & 540 & $\begin{array}{l}\text { Rotating } \\
\text { lens/mirror } \\
\text { (internal tracking) }\end{array}$ & \\
\hline SunFish & Denbighshire, UK & HCPV & $\begin{array}{l}\text { Heliostat, hybrid } \\
\text { PV and thermal }\end{array}$ & \\
\hline Valldoreix Greenpower & $\begin{array}{l}\text { Valldoreix, } \\
\text { Spain }\end{array}$ & 800 & Lens & \\
\hline ZettaSun & Boulder, CO, USA & $\begin{array}{l}\text { Up to } \\
1,000\end{array}$ & $\begin{array}{l}\text { Lens, internal } \\
\text { tracking }\end{array}$ & \\
\hline
\end{tabular}

Table 6: Summary of HCPV module companies.

\begin{tabular}{lllll|}
\hline Fraunhofer ISE | NREL & CPV Report 1.1 & December 2015 & TP-5J00-65130 & 24 | 25
\end{tabular}

Fraunhofer ISE is a member of the Fraunhofer-Gesellschaft, Europe's largest application-oriented research organization. 
*If more than one concentration is listed, the company sells multiple modules which each have different concentration ratios. If this column says "HCPV," that means public information on the exact concentration ratios for that company could not be found.

** Becar-Beghelli is developing a HCPV system within the EU-funded project ECOSOLE together with other partners.

\begin{tabular}{|c|c|c|c|c|}
\hline Company & Location (HQ) & Conc.* & Type of System & $\begin{array}{l}\text { Installed } \\
\text { Capacity } \\
{[\mathrm{MW}]} \\
\end{array}$ \\
\hline SunPower & $\begin{array}{l}\text { San Jose, CA, } \\
\text { USA }\end{array}$ & 7 & $\begin{array}{l}\text { Linear reflective trough, c- } \\
\text { Si cells }\end{array}$ & 8.0 \\
\hline Abengoa Solar & Madrid, Spain & $2-4$ & Mirror & 1.3 \\
\hline $\begin{array}{l}\text { Absolicon Solar } \\
\text { Concentrator }\end{array}$ & $\begin{array}{l}\text { Harnosand, } \\
\text { Sweden }\end{array}$ & 10 & $\begin{array}{l}\text { Reflective through, Si } \\
\text { cells, thermal hybrid }\end{array}$ & 0.1 \\
\hline Whitfield Solar & UK & 40 & Fresnel lens, c-Si cells & $<0.1$ \\
\hline Banyan Energy & $\begin{array}{l}\text { Berkeley, CA, } \\
\text { USA }\end{array}$ & 10 & $\begin{array}{l}\text { Total internal reflection } \\
\text { optics, c-Si cells }\end{array}$ & \\
\hline GreenField Solar & $\begin{array}{l}\text { Cleveland, } \\
\text { Ohio, USA }\end{array}$ & MCPV & Reflective & \\
\hline$\underline{\text { IDHelio }}$ & France & 50 & $\begin{array}{l}\text { Fresnel mirror, hybrid PV } \\
\text { and thermal }\end{array}$ & \\
\hline Pacific Solar Tech & $\begin{array}{l}\text { Fremont, CA, } \\
\text { USA }\end{array}$ & Multiple & Dome lens, c-Si cells & \\
\hline Stellaris & $\begin{array}{l}\text { North Billerica, } \\
\text { MA, USA }\end{array}$ & 3 & $\begin{array}{l}\text { Static, "See-through" PV } \\
\text { window tiles, c-Si cells, } \\
\text { building-integrated CPV }\end{array}$ & \\
\hline Sunengy & $\begin{array}{l}\text { Sydney, } \\
\text { Australia }\end{array}$ & LCPV & $\begin{array}{l}\text { Fresnel, c-Si cells, module } \\
\text { floats on water }\end{array}$ & \\
\hline Sunseeker Energy & $\begin{array}{l}\text { Schindellegi, } \\
\text { Switzerland }\end{array}$ & LCPV & Lens & \\
\hline Zytech Solar & Zaragoza, Spain & 4,120 & Prismatic lens, c-Si cells & \\
\hline
\end{tabular}

Table 7: Summary of LCPV module companies.

*If the system is hybrid PV and thermal, only electric energy generation shown in this table 